\title{
Calcite Mineral Generation in Cold-Water Travertine Huanglong, China
}

\author{
F. Wang, F. Dong ${ }^{(凶)}$, X. Zhao, Q. Dai, Q. Li, Y. Luo, and S. Deng \\ School of Environment and Resource, \\ Southwest University of Science and Technology, Mianyang, China \\ fqdong@swust.edu.cn
}

\begin{abstract}
Mineral generations could help us to understand the physical, chemical and biological processes within their formation, and then to reconstruct the sedimentary paleo-environment and paleo-climate. The calcite in the Huanglong cold-water travertine can be divided into three mineral generations, which reveal two different sedimentary environment systems respectively. In the calcium cycle, calcite mineral generation exposes a step in recycling marine matter to the land, and it also allows the land to proliferate, which mainly manifeste in the addition of plant debris, algae and microbial residues, so that the topography has been accumulating.
\end{abstract}

Keywords: Cold-water travertine $\cdot$ Mineral generation $\cdot$ Paleo-environment $\cdot$ Huanglong

\section{Introduction}

Calcite is the main mineral component of travertine/tufa, and it plays a decisive role in the sedimentary evolution of travertine, whether inorganic or bio-organic (Pentecost 1995). The size of the calcite in travertine is a reflection of the deposition rate and can therefore be used to characterize its sedimentary environment, which is the result of physical, chemical and biological synergy during the deposition process. Herein, we divide the calcite in the Huanglong cold-water travertine into different mineral generations according to the sedimentary environment and evolution time series, i.e., from the generation of the parents to the descendants. The classification of these mineral generations helps to understand the physical, chemical and biological processes within their formation, and then to reconstruct the sedimentary paleo-environment and paleoclimate. On the other hand, the mineral generation of calcite will help to understand the architecture of travertine landscape (Wang et al. 2018), so that they can be better protected and leave more natural heritage of travertine for human beings.

\section{Methods and Approaches}

A comprehensive field geological survey of rocks consisting of calcite was performed, mainly from sedimentary rocks, and systematic sample collection based on the geological background of these rocks was carried out. The mineralogy studies of calcite 
were carried out by polarized light microscopy, XRD and SEM to determine their generational relationship.

\section{Results and Discussion}

From the diagenetic time series of calcite, the types of rocks are Mesozoic limestone and dolomite, and the travertine deposited since the Late Cenozoic. The calcite in travertine is further divided into two mineral generations, namely calcite and secondary in primary travertine travertine. The calcite in travertine is further divided into two mineral generations, namely calcite in primary travertine and calcite in secondary travertine. Therefore, calcite is divided into three generations from the generation of the parent to the descendants, i.e., calcite in the Mesozoic carbonate rock, calcite in the Late Cenozoic travertine, and calcite re-precipitated after travertine leaching.

The calcite in the Mesozoic limestone is micritic, microcrystal and sparry calcite, ranging in size from centimeters to micrometers. $\mathrm{CaO}$ and $\mathrm{MgO}$ in the rocks composed of these calcite are close to the theoretical value, and the other components are very low, which belong to the soluble carbonates. These calcite became the parent generation in the whole calcite evolution sequence, and they provided the material source for the calcite of later generations after being leached. The calcites of the descendants form the different morphologies of the cold-water travertine. During the formation process, physical, chemical, biological and other factors participate in the diagenesis. Among these travertines, no matter what color, except for calcite, other minerals hardly develop. The calcites of the descendants of travertine are very numerous and complex. Here, we mainly listed two of them, which are calcite in the laminal travertine and calcite in the porous travertine, because these are the main components of most travertines. The calcite of the laminal travertine is long columnar and slablike. The brown and white calcite is continuously growing without interruption. These characteristics are very different from those observed on the eye assay, which indicates that the calcite growth in the dry and cold seasons is continuous (Wang et al. 2014). On the other hand, it reflects that the hydrodynamic conditions are very stable, and the water layer is very thin with little or no biological involvement. The calcite in the porous travertine tends to be granular, and the particle size is much smaller than that of the laminal travertine, and its particle size is generally less than $100 \mu \mathrm{m}$. These characteristics reflect the rapid crystallization of calcite, Due to the strong hydrodynamics and the participation of biological effects, calcite cannot be continuously grown, but suddenly nucleates and grows to a certain extent then no longer grows.

The last generation of calcite is the secondary calcite in travertine. The ancestral body of this type of calcite is the deposited travertines, which are dissolved in the water by weathering and leaching, then the calcite re-precipitates through the deposition of a parent-like travertine. These calcites will adhere to the cracks, edges and even the surface of the primary calcite. 


\section{Conclusions}

The calcite in the Huanglong cold-water travertine can be divided into three mineral generations, which reveal two different sedimentary environment systems respectively. They are the generations of the marine carbonate rock diagenesis system, and the descendant generation is the continental freshwater karst sedimentary system. Unlike conventional weathering, which converts terrestrial carbonate rocks to the ocean phase, this is done in the opposite direction. The study of different calcite mineral generation can reconstruct the paleo-environment and paleo-climate of its sedimentation.

Acknowledgements. This research was supported by National Natural Science Foundation of China (Grants nos. 41572035, 41603041 and 41877288), the Open Funds of Key laboratory of mountain hazards and surface processes (grant No. 19zd310501) and Longshan Talents program of Southwest University of Science and Technology (181zx663).

\section{References}

Pentecost A (1995) The quaternary travertine deposits of Europe and Asia Minor. Quaternary Sci Rev 14(10):1005-1028

Wang HJ, Yan H, Liu ZH (2014) Contrasts in variations of the carbon and oxygen isotopic composition of travertines formed in pools and a ramp stream at Huanglong Ravine, China: implications for paleoclimatic interpretations. Geochimica et Cosmochimica Acta 125:34-48

Wang FD, Dong FQ, Zhao XQ (2018) The large dendritic fissures of travertine dam exposed by Jiuzhaigou earthquake, Sichuan, southwestern China. Int J Earth Sci 107(8):2785-2786

Open Access This chapter is licensed under the terms of the Creative Commons Attribution 4.0 International License (http://creativecommons.org/licenses/by/4.0/), which permits use, sharing, adaptation, distribution and reproduction in any medium or format, as long as you give appropriate credit to the original author(s) and the source, provide a link to the Creative Commons license and indicate if changes were made.

The images or other third party material in this chapter are included in the chapter's Creative Commons license, unless indicated otherwise in a credit line to the material. If material is not included in the chapter's Creative Commons license and your intended use is not permitted by statutory regulation or exceeds the permitted use, you will need to obtain permission directly from the copyright holder.

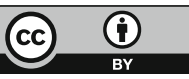

